\title{
THE RIGHT TO HEALTH AND THE SOCIAL DETERMINANTS OF HEALTH IN THE FACE OF COVID-19. THE SPANISH EXPERIENCE AFTER AUSTERITY POLICIES
}

\author{
CARLOS LEMA AÑÓN ${ }^{1}$
}

\begin{abstract}
The COVID-19 pandemic has particularly affected Spain in 2020. Although the specific causes and Spain's response - as well as the aspects to be improved - are yet to be evaluated, many experts agree that this crisis has magnified some of the problems of the Spanish health system, highlighting the problems derived from the cuts in the capacities of the health and public health systems. We assess the current situation from the perspective of the right to health in its twofold dimension: health care and social determinants. For this purpose, we look into the configuration of the right to health in Spain and how the economic crisis and austerity policies affected it. In particular, we consider the impact both on institutional health care systems and in terms of social determinants of health. Finally, we make several proposals for strengthening the right to health.
\end{abstract}

Keywords: Right to Health, COVID-19, Social Determinants of Health, Austerity Policies.

Summary: 1. The impact of the COVID-19 pandemic. 2. The evolution of the right to health in Spain. 3. THE CONSEQUENCES OF AUSTERITY POLICIES ON THE HEALTH SYSTEM. 3.1. The legal framework of the austerity policies in health care. 3.2. The consequences of the austerity policies in health care. 4. SocIAL CRISIS, INEQUALITY AND THE SOCIAL DETERMINANTS OF HEALTH. 5. ELEMENTS FOR STRENGTHENING THE RIGHT TO HEALTH.

\section{The IMPaCt OF THE COVID-19 PANDEMIC}

The COVID-19 pandemic caused by SARS-CoV-2 virus, which has affected millions of people worldwide, has had a major impact on Spain. It was one of the hardest hit countries during the first wave, between March and June, and it has also been severely affected by the second (The Lancet, 2020). As of December 15, 2020, confirmed cases exceeded $1,930,000$, and the number of confirmed deaths was 50,837 . It is generally assumed - and Spain is no exception - that the confirmed figures underestimate the actual numbers. Seroepidemiological studies carried out by Carlos III Health Institute (ISCIII) estimate that the cumulative prevalence may have reached $9.9 \%$ of the population (ISCIII, 2020; Pollán et al., 2020), which would mean more than 4.5 million cases. As to the number of deaths, according to estimates by the National Statistical Institute (INE) based on excess deaths and civil registration data, by May 2020 more than 45,000 people would

\footnotetext{
${ }^{1}$ Professor of Philosophy of Law. Instituto de Derechos Humanos Gregorio Peces-Barba. Universidad Carlos III de Madrid, Spain (carlos.lema@.uc3m.es). ORCID: 0000-0003-0889-3272. PROJECT DER2016-76078-P "Condicionantes sociales de la salud y justicia: los desafíos del derecho a la salud", del Programa Estatal de Investigación Científica y Técnica de Excelencia del Ministerio de Economía, Industria y Competitividad.
} 
have died from COVID-19, contrasting with the official figure of 28,000 confirmed deaths for that period ${ }^{2}$.

Already in August 2020, a group of Spanish scientists published a letter in The Lancet medical journal calling for an independent evaluation of Spain's response to COVID-19, not as a way to seek responsibility, but to identify areas for improvement (García-Basteiro, 2020a). ${ }^{3}$ Pending such evaluation, either official or based on multidisciplinary research, these scientists pointed to some potentially relevant elements, such as the lack of pandemic preparedness (weak surveillance systems, low testing capacity, etc.), a delayed reaction by the authorities, slow decision-making processes, poor coordination, high levels of population mobility, an ageing population, the existence of vulnerable groups experiencing health and social inequalities, and a lack of preparedness in nursing homes. The relative importance of these or other elements is something that remains to be determined and will require an effort that cannot be addressed here. Nevertheless, these researchers also referred to the general situation of the public health system: "These problems were exacerbated by the effects of a decade of austerity that had depleted the health workforce and reduced public health and health system capacities" (García-Basteiro, 2020a: 529).

Several analysts share the view that, regardless of the specific, more or less appropriate responses to the pandemic and sociological, demographic or behavioral realities, it is necessary to consider the previous situation of the public health systems - and, in some cases, their deterioration. Thus, an editorial in The Lancet agreed that the COVID-19 crisis had magnified some weaknesses of the Spanish health system (The Lancet, 2020). Again, Spain is no exception. In a comparative review of the triage criteria implemented in different countries during the pandemic, the authors remark how such processes have revealed many weaknesses in all health systems. Until now, many of these problems had been overlooked because they manifested themselves at the individual rather than the systemic level (Jöbges et al., 2020:958). It could even be argued that the shortcomings found within national health systems reflect more general trends emerging from a deterioration of the global health system understood as a common good (Garrett, 2001).

Therefore, a more detailed assessment will be necessary to determine why the pandemic has affected us with such intensity. However, it is also worth examining the state of the right to health in Spain when the pandemic needed to be faced. This, in turn, requires considering the actual impact of the decade of austerity in this right. Conceptually, austerity policies can affect health through two mechanisms (Stuckler et al. 2017: 18). On the one hand, through the effect on health protection systems themselves resulting, among others, from cuts to health care services, coverage reductions or access restrictions. On the other hand, through a "social risk effect" due to increasing unemployment, poverty and other risk factors, as well as through cuts in welfare programs that can mitigate these health risks. We will analyze the effect of austerity policies in Spain on public health,

\footnotetext{
${ }^{2} \mathrm{https}: / / w w w . i n e . e s / e x p e r i m e n t a l / d e f u n c i o n e s / e x p e r i m e n t a l$ defunciones.htm.

${ }^{3}$ In November, they outlined some criteria and requirements for this evaluation (Garcia-Basteiro et al., 2020b)
} 
the health care systems, and health protection mechanisms, on the basis of this twofold approach. Thus, we will assess both the effect on health protection systems and the social risks to health that may have been triggered by such policies.

The perspective of rights, and specifically the right to health, provides a common framework for both approaches. In accordance with international regulations, the right to health must be understood as "the right of everyone to the enjoyment of the highest attainable standard of physical and mental health," as enshrined in Article 12 ICESCR. This means, among other things, that the right to health should not be identified exclusively with the right to health care, as is sometimes hastily done. And much less with health care understood as a response to disease from a hospital-centric perspective. Obviously, the right to health comprises the right to health care, but also other measures ranging from prevention and public health approaches to the impact on the various factors that affect people's health, including social and environmental factors. The aim of enjoying "the highest attainable standard" of health, in short, calls for attention to the various social and institutional mechanisms that can promote it, whether these are purely medical or not. In this regard, the right to health must be understood as "a right to the socially controllable determinants of health" (Hassoun, 2020: 158), that is, the right to an equal access to such determinants. And these are precisely the two dimensions referred to above: health care systems and social determinants of health—both constituent of the right to health.

This twofold perspective-medical and social-required for a complete assessment of the right to health underpins the proposal to reconceptualize the COVID-19 pandemic as a "syndemic." In fact, the proposal comes from The Lancet's editor-in-chief, Richard Horton (2020), who points out how COVID-19 infections interact especially in certain populations with other non-communicable diseases, so that "these conditions are clustering within social groups according to patterns of inequality deeply embedded in our societies. The aggregation of these diseases on a background of social and economic disparity exacerbates the adverse effects of each separate disease" (Horton, 2020: 874). Consequently, analyzing COVID-19 in syndemic terms requires taking into account its social origins, as well as the special vulnerability of certain groups (the elderly, minorities, precarious workers, etc.), in order to approach it not only from a biomedical perspective but also by addressing the profound existing social inequalities.

The way in which the right to health — and other related rights — have been affected in Spain by the COVID-19 pandemic and its management is a broader question that cannot be thoroughly examined here. However, it is worth mentioning the most salient issues. ${ }^{5}$ First, there is evidence of serious lack of protection of the rights of the elderly in

\footnotetext{
${ }^{4}$ The notion of "syndemic" was first developed by a medical anthropologist, M. Singer, to conceptualize interactions between diseases that are exacerbated by inequality, poverty or structural violence (Singer, 2009).

${ }^{5}$ As regards other rights, the Constitutional Court has only ruled on the right to demonstrate during the State of Alarm. In this case, the Constitutional Court considered the limitation introduced by Order 40/2020, of April 30, justified under Articles 15 (right to physical integrity) and 43 (right to health protection) of the Constitution. Therefore, the Court rejected the appeal for protection (recurso de amparo) against the decision not to authorize a demonstration in Vigo on May 1.
} 
nursing homes, where it is estimated that almost half of the deaths occurred during the first months of the pandemic (AI, 2000: 4). Amnesty International has published a report on these cases denouncing a violation of the human rights of older people living in care homes, in particular their right to health, life, and non-discrimination. The problem was particularly severe in Catalonia and Madrid (AI, 2020), where there was a "general and discriminatory exclusion from access to hospital care" (AI, 2020: 6), with no realistic alternative treatments. Second, and closely related to this, was the question of hospital treatment prioritization and in particular access to intensive care units at times of great pressure due to the continuous influx of patients. This issue, with major ethical, legal and human rights implications, emerged in various countries both at a theoretical level and through the establishment of public criteria to address it. The resulting standards share some common features but also differ significantly across countries (Ehni et al., 2020; Jöbges et al., 2020). In Spain, beyond the aforementioned legally and ethically questionable actions in relation to nursing home management, efforts have also been made to define public criteria that reflect ethical and legal principles such as the prohibition of discrimination - including age discrimination (Ministry of Health, 2020; González Suárez, 2020). Third, the availability of vaccines raises the question of access and prioritization. In addition to the epidemiological and logistical dimensions, ethical and human rights issues must be considered along with structurally disadvantaged groups (Schmidt, 2020). These and many other open questions are linked to the right to health during the COVID-19 pandemic. However, for all the above reasons, this work focuses on the state of the right to health in Spain at a time of undoubtedly exceptional circumstances. Health protection mechanisms and systems were placed under extreme pressure, but there are good reasons to believe that they were already operating at their limits.

Below we will first examine the configuration of the right to health in Spain, considering its constitutional design as well as its legal, institutional and material evolution. Then, we assess the impact of the austerity policies implemented over the last decade, which have affected public health infrastructure as well as prevention and research - in addition to entailing significant cutbacks in equipment and personnel. From the abovementioned perspective based on the right to health, we evaluate the effect of such policies (i) on institutional health care systems; and (ii) on health and social determinants of health. Finally, we make several proposals for strengthening the right to health in Spain.

\section{The EVOLUtion of THE Right to Health in SPAiN}

Whatever the diagnosis on the state of the right to health in Spain and the related issues, it is worth putting into perspective its - overall positive-evolution since its recognition at the end of the 1970s. Indeed, the starting point was a deficient and incomplete public system where the provision of services did not qualify as a right. The momentum for reform, democratization and modernization allowed the development of a complete, universal and decentralized public health system. Despite its shortcomings, it has been regarded as the best national public service, "with the essential characteristics to provide care to all citizens, based on equity and solidarity, with a relatively high level of quality and at a reasonable cost with respect to the country's wealth" (Álvarez González, 2007: 22). 
From the regulatory standpoint, the notion of the right to health was incorporated by the International Covenant on Economic, Social and Cultural Rights, which came into force in Spain in 1977. Its Article 12 reads as follows: "The States Parties to the present Covenant recognize the right of everyone to the enjoyment of the highest attainable standard of physical and mental health." It thus establishes an international standard linking this right to other rights such as food, housing, work, education, life, non-discrimination, equality, freedom from torture, privacy and access to information. The 1978 Spanish Constitution ${ }^{7}$ incorporated the right to health in its Article 43: "1. The right to health protection is recognized. 2. It is incumbent upon the public authorities to organize and safeguard public health by means of preventive measures and the necessary benefits and services. The law shall establish the rights and duties of all concerned in this respect. 3. The public authorities shall promote health education, physical education and sports. Likewise, they shall encourage the proper use of leisure time." ${ }^{\prime}$

The constitutional recognition of this right entails a series of mandates for its implementation. As is well known, it is systematically placed among the Governing Principles of Economic and Social Policy. This means that it is not acknowledged as a fundamental right with the maximum guarantees, so it does not confer an immediate entitlement subject to effective judicial protection. However, it is still an actual right with legal weight, even if it must be further developed by the relevant implementing legislation. Indeed, it has legal force in the sense that it constitutes a mandate to public authorities, who must develop and implement it. It also sets a limit to governmental action and provides an interpretative criterion for the entire legal system, as well as a standard for the basic conditions guaranteeing the equality of all citizens (Art. 149(1)(1)). On the other hand, from a systematic point of view, the right to health is connected with the substantive equality clause of Article 9(2) and with the right to life and integrity under Article 15 (León Alonso, 2009: 165-170). Therefore, the connection with clauses enjoying greater constitutional protection opens a way for an indirect guarantee. Furthermore, the aforementioned international recognition of this right also imposes standards of legal protection.

The content of the right to health-both in its subjective and objective scope-can be derived from the Constitution in spite of its brief formulation. It is certainly a complex

\footnotetext{
${ }^{6}$ The interpretation of this article is developed in the General Comment No. 14: The right to the highest attainable standard of health (article 12) (2000), Adopted by the Committee on Economic, Social and Cultural Rights (E/C.12/2005/4, 11 August 2000).

${ }^{7}$ The 1931 Constitution was an advanced precedent for its time, even if its wording was rather undeveloped. Its Article 43 established that, "The State shall provide assistance to the sick," complemented by the establishment of health insurance for workers (Art. 46). All this, under Title III on rights and duties, which makes it clear that it is conceived as a right.

${ }^{8}$ Although the Constitution uses the expression "right to health protection," with extensive presence in the Spanish legal literature (Pemán Gavín 1989: 28, Menéndez Rexach, 2003: 17), we will use the internationally more widely accepted expression of "right to health." There is no conceptual difference between both formulations, which should be understood in accordance with the international standard ("the highest attainable standard of physical and mental health") enshrined in the ICESCR - i.e., in terms of equal access to the determinants of health rather than just to health care.
} 
right, including different obligations, as well as positive and other mandates (abstention), entitlements or benefits, promotion of health, etc. It is also intricately linked to other rights, as can be seen from a systematic perspective within the framework of the social or welfare State (Art. 1(1)) and the promotion of material equality (Art. 9(2)). As for the subjective scope of the right (i.e., its holders), a universality and an equality mandate stem from the Constitution. The former has been gradually fulfilled since the adoption of the General Health Act 14/1986, establishing in Article 1(2) that all Spanish citizens and "foreign nationals resident in Spain" are entitled to the right to health and health care. 9 With regard to the equality mandate, the transfer of health care powers to the autonomous regions (pursuant to Article 148(1)(21) of the Spanish Constitution) has raised the question of whether the content of health care services can be different in each region. Insofar as the State holds exclusive competence over the bases and general coordination of health matters, legislation on pharmaceutical products (Art. 149(1)(16)), as well as the "regulation of the basic conditions guaranteeing the equality of all Spaniards in the exercise of their rights" (Art. 149(1)), the possibility for autonomous regions to provide additional benefits has not been problematic (see, in this regard, Judgment 98/2004 of the Spanish Constitutional Court). The greatest challenges to the equality mandate come from inequalities and inequities not in benefits but in health outcomes at the regional level, disparities between rural and urban areas, and above all from health inequities driven by socioeconomic inequalities, as we will see below.

Although the objective scope of the right to health derived from Article 43 seems rather undetermined, its minimum content must be defined based on the principle of progressive realization enshrined in Article 2(1) ICESCR and in accordance with the relevant international standards, including General Comment No. 14 of the Committee on Economic, Social and Cultural Rights (Escobar Roca, 2008: 537, Pemán Gavín, 2008). ${ }^{10}$

As already mentioned, the Constitution refers to ordinary legislation for the implementation of the right to health. This development took place speedily and with guarantees - not only at the regulatory level but also in the public policy specification of the right, as well as in the strengthening of the health system in accordance with the Constitution. This required institutional, organizational and financial resources in addition to legal mechanisms. The adoption of the 1986 General Health Act completed the regulatory implementation of Article 43 of the Constitution, thus defining the right to health as a subjective, universal, legally enforceable right subject to judicial protection with a broad guaranteed content.

\footnotetext{
${ }^{9}$ Nevertheless, as we shall see, this mandate has been subject to swings, especially with Royal Decree-Law $16 / 2012$

${ }^{10} \mathrm{~A}$ more complex question is whether this includes a prohibition of retrogression. In its General Comment No. 14, on Right to the highest attainable standard of health, the Committee on Economic, Social and Cultural Rights argues that there is a strong presumption that retrogressive measures on the right to health are not permissible. In any case, it is for States parties to prove that they have been introduced after careful consideration of possible alternatives. In a similar vein, Añón has convincingly argued that such decisions are legally constrained by a number of safeguards ultimately aimed at protecting the right in question (Añón, 2016).
} 
In terms of financing, it went from a system in which almost three quarters of public health spending was financed by labor contributions, to a system (since 1989) fully financed by general taxation. Thus, by unequivocally establishing the universality of the right to health, the General Health Act 14/1986 updated and changed the modelpreviously linked to labor conditions and now based on universalized social citizenship. In the same vein, it created the National Health System (Sistema Nacional de Salud or SNS) based on the integration of all public health services and conceived as an institutional guarantee of the right to health (Monereo and Molina, 2007). The SNS is in turn made up of the coordinated set of Health Services of the autonomous regions, since they have assumed health-related competences. The central government retains certain powers in accordance with the Constitution, such as the bases and general coordination of health. ${ }^{11}$

The starting point for the development of a health system based on rights-driven social policies was inadequate and far from the European benchmarks. Public spending on health as a percentage of GDP in Spain in 1980 was 4.5\%, far below the European Union average. The evolution of this figure in the following years shows the enormous progress made in the modernization and consolidation of the public health system securing the right to health. At the same time, it reveals some shortfalls in relation to the most advanced European benchmarks. By 2000 it had already risen to 6\%, although the European average stood at 7.5\%. In 2009, it reached a maximum of 7.2\%, above the EU average, which in turn had decreased after the accession of the Eastern European countries. In any event, it remained far from the leading countries such as France and Germany, which reached $9 \%{ }^{12}$.

Despite all its limitations, the fact that this indicator is not expressed in absolute numbers but in relation to the national wealth makes it comparable among countries, thus opening the way to arguments for greater financial effort in Spain. Moreover, if we look at health expenditure per capita, in 2019 Spain spent $€ 2,451$, below the EU average $(€ 2,572)$, close to Italy $(€ 2,473)$ and Portugal $(€ 2,290)$, but far from Germany $(€ 4,504)$ and - outside the EU-Norway (€4,505) (OECD, 2020: 159). Similarly, Spain's public spending in relation to the country's total health expenditure is also below the European average. EU's average spending as percentage of GDP was $8.3 \%$ (a figure that has remained relatively stable since 2014 ), ranging from $11.7 \%$ in Germany and $11.2 \%$ in France to $5.7 \%$ in Romania. Spain's $9 \%$ is above the average, but only $6.4 \%$ is public spending - the remaining $2.6 \%$ being private out-of-pocket spending (OECD, 2020: 163). This means that only $70.8 \%$ corresponds to public spending, below the European average of $74.1 \%$ and far below Germany $(85 \%)$, France $(83.7 \%)$ or Sweden $(85.2 \%)$.

In short, if we compare different statistics on the state of the National Health System and health outcomes in the European context, the findings are in line with our conclusions. There are positive indicators (especially in light of the transformation undergone in the last

\footnotetext{
${ }^{11}$ In this regard, once the transfer of powers to the autonomous regions was completed, Act 16/2003 reorganized the system's coordination mainly through the Interterritorial Council (created by the General Health Act)

${ }^{12}$ https://ec.europa.eu/eurostat/databrowser/view/tps00207/default/table?lang=en.
} 
decades) such as the comparatively low level of unmet health care needs, the number of physicians per inhabitant, and avoidable mortality (preventable and treatable). However, other indicators are comparatively far from the best performers and clearly below average, such as the availability of hospital beds per capita, the number of nurses per capita, or waiting times for operations (OECD/European Union, 2020; 176, 204, 212, 218, 222, 226).

\section{The CONSEQUENCES OF AUSTERITY POLICIES ON THE HEALTH SYSTEM}

The 2008 economic crisis affected the National Health System, among other things, by reducing health expenditure per capita, which until then had been increasing and approaching the European average. The annual growth rate in real terms (adjusted for inflation) was negative in the period 2008-13 (-1.4\%), higher only than Greece, Portugal, Croatia and Cyprus (OECD/European Union, 2020). ${ }^{13}$ This undermined the System, leading to underfunding and - as we will see-a deterioration in the conditions of the right to health itself, both in terms of benefits and its holders. In any case, it is worth considering to what extent the setbacks can be attributed to the crisis or rather to the neoliberal and austerity measures implemented to tackle it. M. Calvo has convincingly supported the second hypothesis, blaming this deterioration on "the long-standing neoliberal attack against social rights, reinforced in recent years on the pretext of the crisis" (Calvo, 2013: 111). The EU's approach to the crisis, focusing on budgetary balance through major adjustment measures (including reductions in public expenditure) would have significantly affected welfare policies, education, health care, and social rights in general (Calvo, 2013: 117). Therefore, it could be argued that governments did not perceive health care as a priority but as a reserve for budget cuts (Palasca and Jaba, 2015: 531). However, not all EU countries implemented the same policies or targeted the health sector with the same intensity (Karanikolos et al., 2013: 1324-5) ${ }^{14}$.

\subsection{The legal framework of the austerity policies in health care.}

In the case of Spain, this type of policies strikingly undermined - at least in partsome aspects of the national system until then regarded as the most outstanding: universal coverage, public financing through progressive taxation, public provision of services, and access to health services and products without costs or barriers for patients. The main measures implemented can be classified into cutbacks, privatization, and segmentation. We will address each of them separately.

Although the general shift towards austerity in Spain began in the second half of 2010, the main legal instrument defining the response to the economic crisis in the health sector was Royal Decree-Law 16/2012, of April 30, on urgent measures to guarantee the sustainability of the National Health System and improve the quality and safety of its services. It systematized some responses, but certain measures-especially those related

\footnotetext{
${ }^{13}$ Health spending per capita returned to a positive path in the period 2013-2019, with an annual rate of $2.3 \%$, still below the European average of 3\% (OECD/European Union, 2020: 158).

${ }^{14}$ Some countries such as Belgium and Denmark did not reduce their health budgets, even if other sectors experienced cuts (Karanikolos et al., 2013: 1324).
} 
to cuts and privatization - were implemented through other mechanisms such as budgets. The outcome was not entirely homogeneous across autonomous regions. ${ }^{15}$

Regarding the cuts, apart from the drop in public spending per capita and in relation to GDP, some regulations such as RDL 16/2012 segmented the services offered by the health system. This allowed some autonomous regions to reduce their services to the lowest common while introducing "copayment" by means of economic contributions from patients. The aim was to contribute to the financing of health expenditure and to reduce demand. This measure is not blatantly contrary to international law, since the corresponding obligation is not one of gratuity but of accessibility (Escobar Roca, 547; Pemán, 2008: 55). However, even if these measures do not generate accessibility problems - which is far from certain ${ }^{16}$ - placing the funding burden on patients is highly questionable from the system-wide perspective. Therefore, this option unfairly blames the patient while promoting the commodification of the services in the health sector (Benach et al., 2012: 72). Beyond these issues and in addition to excluding certain benefits, budget cuts sometimes involved the closure of services and health centers, and especially personnel reduction. They also have been associated with increases in waiting lists and delays in obtaining treatment (Legido-Quigley et al., 2013), which also affected the most vulnerable sectors (López-Valcárcel and Barber, 2017: 18). Thus, between 2012 and 2014 the number of workers in the National Health System was reduced by 28,500 (CerveroLiceras et al., 2014: 101). ${ }^{17}$ In addition, the cuts have disproportionately affected certain areas, such as public health programs (Legido-Quigley et al., 2013).

Secondly, privatization trends in the health sector should be considered in the broader context of commodification processes. This makes them especially problematic from the point of view of the right to health, since the functional logic of social rights is precisely the opposite, that of decommodification (Esping-Andersen, 1990: 37ss.). Public health privatization is not legally prohibited at the national or international level, but it can undermine the effectiveness of the right to health (Toebes, 2006: 107; Escobar Roca, 2008: 543). Act 15/1997, of April 25, on enabling new forms of management of the National Health System, laid out the legal basis for privatization in the health sector. This trend was reinforced by the responses to the 2008 crisis, albeit with wide disparities across autonomous regions, and has manifested itself in different ways: deregulating public health services, separating financing from provision, granting the management of public centers

\footnotetext{
${ }^{15}$ On a comparative level, some European countries implemented budget cuts, particularly in the hospital and pharmaceutical field, restructured hospital services, froze salaries, reduced the services provided by the public health system, reduced the population covered and introduced copayments (Karanikolos et al., 2013: 1325).

${ }^{16}$ On the contrary, after a thorough review of the relevant literature, Gremmill et al. Conclude that copayments are only efficient in the narrowest economic sense: on the one hand, they do not lead to long-term spending reduction but only end up shifting costs; on the other hand, there is evidence of negative health outcomes and worse treatment adherence rates; finally, "international evidence consistently demonstrates that user charges are a regressive form of health care finance, requiring the poor to pay more for health care as a proportion of their income than the rich" (Gremmill et al. 2008).

${ }^{17}$ Between 2011 and 2015, 3,000 doctors, 5,000 nurses and 40,000 other health care jobs were lost due to budget cuts (Cabrera et al., 2018: 1095).
} 
to private operators and also favoring private insurance. Privatization trends have followed complex paths, including changes in the composition of health expenditure. According to Santos's analysis, a common mechanism is the modification of public spending on social policies, seeking to attract private capital to the production of these goods and services. Hence, public social spending is redirected to equipment production instead of laborintensive policies (Santos 1992:210).$^{18}$ Another aspect of the drive towards privatization was the adoption of measures promoting complementary private insurance for coverage not included in the public system (Legido-Quigley et al. 2013). This was especially the case in those autonomous regions most affected by cuts, where the perception of the deterioration of public health was greater (FOESSA, 2019: 334).

Finally, segmentation was one of the main consequences of RDL 16/2012, since to be covered by the public health care system the condition of insured or beneficiary of an insured person was subject to certain requirements (mostly linked to employment status). At its most extreme, this segmentation entailed the expulsion ${ }^{19}$ of entire groupsmainly foreigners in an irregular situation-who came to exceed 900,000 (FOESSA, 2019: 333). ${ }^{20}$ Conceptually, in addition to the consequences of each specific expulsion, this implied an abandonment of the universal logic underlying the notion of rights andalthough nominally maintained - the abandonment of very logic of the National Health System itself. It meant, in short, the abandonment of the idea of the right to citizenship in favor of an insurance logic. This situation was reversed by Royal Decree-Law 7/2018, of July 27, on universal access to the National Health System, which expressly returned to a rights-based logic by establishing that, "all Spanish nationals and foreign nationals resident in Spain are entitled to the right to health and health care." In any event, beyond the specific consequences of RDL 16/2012 after 6 years in force, one of the most lasting effects was the validation of its constitutionality - except for some minor aspects - by Judgment 139/2016 of the Spanish Constitutional Court.

Indeed, even if the most unacceptable aspects of the health counter-reform were corrected in 2018, Judgment 139/2016 is problematic both from the point of view of the universal nature of the right and in terms of regressivity. While acknowledging a decline in the universality of the right, the Constitutional Court ruled that the benefitproviding dimension of the right to health did not necessarily entail that all health care services be free for all persons. Therefore, ordinary legislation (being a statutorily-defined right) could establish access conditions - especially for aliens. The Constitutional Court departed from its own case law, established in Order 239/2012, where it had rightly noted that the general economic interest associated with savings had to be weighed against the general interest in preserving the right to health. Furthermore, it had pointed out

\footnotetext{
${ }^{18}$ The autonomous region of Madrid provides a clear example in this regard: 8 new hospitals opened in 2008 within the public health network under major private construction contracts and whose management was granted to private companies. At the same time, between 2008 and 2010, 2,771 hospital professionals were lost.

${ }^{19}$ According to Sassen, expulsion logics are increasingly intertwined with neoliberal policies, either through expulsion from livelihoods, from membership or from the social contract (Sassen, 2014: 29).

${ }^{20}$ Public health care was reduced to emergencies due to serious illness or accident, childbirth and postpartum care, and children under 18.
} 
that the right to health together with the right to physical integrity "possess a singular importance in the constitutional framework and cannot be seen as diminished for the mere consideration of an eventual economic saving" (Legal Ground No. 5). Along the same lines, the United Nations Committee on Economic, Social and Cultural Rights, in its "Concluding observations on the sixth periodic report of Spain," stressed both its concern about the regressive effects of this provision on the right to health and the fact that "no comprehensive impact assessment has been carried out with regard to this law" (UNESC, 2018: 8). In short, the existing legal limitations and guarantees-including under international human rights law - that require a weighing exercise to justify regressive measures (Añón, 2016) do not seem to have applied to this case by the Constitutional Court, which is legally problematic.

Therefore, the Spanish authorities did not weigh the potential rights implications of the measures at the time of their adoption. Nor was there an official ex-post evaluation of their actual impact on the right to the highest attainable standard of health, as recommended by the Committee on Economic, Social and Cultural Rights. Therefore, an assessment of the effects of the austerity measures on the right to health should now be made, not in order to justify whether or not they were appropriate, but to determine to what extent they affected the capacities of the health system and to assess the state of the right to health at a time when it is necessary to respond to the COVID-19 pandemic.

\subsection{The consequences of the austerity policies in health care}

Before addressing the general health effects of austerity policies in the next section, we now focus on the austerity measures that specifically affect the health protection system. Generally speaking, there is sufficient evidence that austerity measures can affect health. In this regard, Stuckler and Basu carried out a global study on the health consequences of times of recession. Based on evidence from historical and present examples, they show that the health of populations is not necessarily affected - and sometimes even improves - in situations of economic crisis. Therefore, they conclude that "the real danger to public health is not recession per se, but austerity" (Stuckler and Basu, 2013: xiv).

However, besides this general conclusion, another question that remains is the extent to which health cuts and other austerity policies can affect health outcomes in developed countries with large health budgets. In a study on the health consequences of austerity policies in Italy, Arcà shows that they can lead to a significant increase in the number of preventable deaths (Arcà et al., 2020). This study is particularly relevant, since only 10 out of 20 Italian regions (mainly in the South) implemented such cuts, generating a sort of natural experiment that made possible a controlled assessment of these policies. Between 2004 and 2014, the regions affected by austerity plans experienced a $3.8 \%$ cut in spending, leading to a 3\% increase in preventable deaths, largely related to cancer. Among the plausible causes for this increase, the study considers the reduction in hospital beds $(6.5 \%)$, in health care workers $(4 \%)$ and in hospitalization rates $(8.5 \%)$. Since only some regions implemented those plans, some patients who had the means sought health care in the northern part of the country. Deficit reduction objectives were achieved, but at the cost 
of an increase in preventable deaths as well as an increase in inequality in access to health care both across and within regions.

No similar study is available in Spain, among other reasons because the situation was different (in the sense of austerity policies being implemented only in some regions). Despite the significant disparities across autonomous regions, all of them were affected by budget restrictions under a general austerity framework. In any event, after analyzing health expenditure data from different autonomous regions between 2008 and 2012, Vallejo-Torres et al. concluded that health expenditure has a positive effect on population health (Vallejo-Torres et al., 2018), even if this study does not measure the distinctive effect of austerity measures compared to other periods. In another significant study, Borra et al. analyze the period 1996-2015 taking as a reference not health expenditure but certain health care inputs such as health workers or available hospital beds, as well as the consequences in terms of mortality rates for specific diseases. Their main finding is that the short-term effects of cuts in health provision have a significant — albeit small —impact on mortality (Borra et al., 2020). ${ }^{21}$ Nevertheless, it should be borne in mind that this study refers only to increases in mortality caused by these reductions, and only in the short term. In other words, it is possible to consider health effects that do not result in mortality, as well as medium-term effects, which are not considered in this study.

From a different standpoint, according to a qualitative study conducted in the autonomous region of Valencia, the general perception of health professionals was that the austerity measures adopted in the health sector hampered access to medicines and health care. In general, and according to their experience, they considered that austerity measures had had a negative effect both on the quality of the public health care system and, in general, on the health of the population (Cervero-Liceras et al., 2014). ${ }^{22}$

In sum, it is complicated to make an accurate assessment of the effects of austerity measures on the health system due to the scarcity of data and the possible mediumterm consequences (López Valcárcel and Barber, 2017) - a problem common to other European countries (Karanikolos, 2013: 1325). Likewise, it is difficult to distinguish between the effects due to this and to other causes. The precariousness of these indicators is a problem inherent to the information mechanisms of the health system, as it hinders a real policy evaluation. However, everything suggests that these policies had significant consequences, thus supporting the hypothesis that the public health system was placed under great pressure and pushed to the limit of its capacity. This, in turn, made it difficult to respond more adequately to the COVID-19 pandemic. The same reasons explain the setback to the right to health associated with austerity policies in the health system.

\section{SOCIAL CRISIS, INEQUALITY AND THE SOCIAL DETERMINANTS OF HEALTH.}

Economic downturns do not necessarily have negative effects on the general health of the population (Ruhm, 2000; Stuckler and Basu, 2013; Karanikolos et al., 2013: 1325; Regidor et al., 2019: 1046). There are plausible explanations for this counterintuitive observation: an increase in beneficial activities (exercise), a reduction in the consumption of unhealthy foods and beverages, or fewer traffic accidents. That does not mean that all 
the effects of economic crises are harmless: for instance, high unemployment is generally associated with health problems. Indeed, the prevalence of psychological problems is more than twice as high among unemployed people, especially in countries with poor employment protection. Unemployment - particularly long-term unemployment - is also linked to higher mortality and an increase in unhealthy behaviors. Moreover, it increases the risk of psychological and behavioral disorders, as well as psychosomatic illnesses and suicides (Karanikolos et al., 2013: 1326). Accordingly, the policies implemented to deal with a crisis are even more relevant to health outcomes than the direct effects of the crisis itself (Stuckler and Basu, 2013; Calvo, 2013). Thus, for example, maintaining the budget for protection programs in sectors other than health may be as important for protecting the population's health as avoiding cuts in budget allocations to the health system (Karanikolos et al., 2013: 1326).

This is known as the "social risk effect" (Stuckler et a. 2017: 18) on health stemming from austerity policies. It refers not to the health system but to issues as increased unemployment, inequality, poverty, and cuts in social programs aimed at mitigating these effects. This effect is largely related to Social Determinants of Health (SDH), i.e., social factors that significantly affect health and drive different health outcomes across or within populations. The WHO defines SDH as "the non-medical factors that influence health outcomes. They are the conditions in which people are born, grow, work, live, and age, and the wider set of forces and systems shaping the conditions of daily life. These forces and systems include economic policies and systems, development agendas, social norms, social policies and political systems." ${ }^{23}$ SDH are present in every society, they are not supervening circumstances caused by an economic crisis. Rather, economic crises, and the corresponding responses, affect social determinants of health such as - in the above example-employment, unemployment, working conditions, and the associated social policies.

The impact of SDH on the health of individuals and populations manifests itself in at least two noteworthy ways: (i) they affect the level of a population's health; and (ii) they affect health inequalities. The way in which SDH affect the level of health of a population is clearly perceptible, for example, in global health disparities associated with economic development or in the historic evolution of health indicators in the last century and a half, when social factors had greater incidence than the advances in clinical medicine itself (McKeown, 1976; House and Williams, 2000: 97). Second, the impact of SDH is visible in social and health inequalities. Research on social determinants of health has found a systematic correlation between social advantages/disadvantages and health outcomes (Hofrichter, 2000; Bartley, 2004; Marmot and Wilkinson, 2006). Social inequalities translate into health inequalities, thus amplifying social inequality. Inequalities in health outcomes occur even when equal access to health care is effectively guaranteed, which confirms that SDH operate beyond - and relatively independently of - health care. As a result of the COVID-19 pandemic, the relationship between disease and inequality has become transparent and evident to many observers. This correlation was already well

${ }^{23} \mathrm{https}$ //www.who.int/health-topics/social-determinants-of-health\#tab=tab_1 (last accessed January 11, 2021). See also Commission on Social Determinants of Health (2008) and WHO (2016). 
known in the field of epidemiology and public health but has not always been given due consideration outside it. It has now come to the forefront. Indeed, the relationship between disease and inequality - linked to the concept of syndemic - has manifested itself in the fact that COVID-driven inequalities are related to previous socioeconomic inequalities and the unequal distribution of non-communicable diseases. Therefore, COVID-19 is not neutral in social terms. Vulnerability to the disease is connected to preexisting social vulnerabilities (minorities, deprived areas, poverty, marginalized groups, etc.). Likewise, disease control measures such as confinements have a social uneven impact. (Bambra et al., 2020).

In Spain, the "social risk effect" associated with changes in SDH due to the economic crisis and austerity became visible, for instance, in higher unemployment, poverty, and social inequality. This may have greater impact on health than direct actions regarding the health system. In the words of López-Valcárcel and Barber, "rising unemployment and poverty, as a result of the crisis, are health risk factors that are much more intense than cutbacks in health spending" (López Valcarcel and Barber, 2017).

Unemployment data are well known: the unemployment rate in 2008 was already significantly higher than the EU average (11.3\% compared to $7 \%)$, and it reached its zenith at $26 \%$ in 2013 (10.8\% in the EU), only behind Greece. This meant a total of $6,200,000$ unemployed. Still in 2019, unemployment in Spain remained above 2008 levels (14.1\% compared to $6.3 \%$ in the EU). ${ }^{24}$ And this without considering the deterioration of employment conditions, the increase in job insecurity or the wage gap.

Poverty and social exclusion also reached extremely high figures: in 2013, 25\% of the population was in a situation of social exclusion (moderate or severe), while only

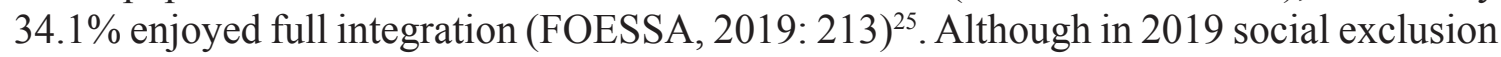
had fallen to $18.4 \%$, the number of people in severe exclusion exceeded four million, $44 \%$ more than in 2007 (FOESSA, 2019: 213). In terms of poverty, 7.3\% of households were in extreme poverty in 2013 (FOESSA, 2014: 159).

In terms of inequality, Spain is not only above the European average, but over the past decade inequality has increased significantly. Spain's Gini index was 32.4 in 2008 and reached the peak of highest inequality in 2014, with 34.7. In 2019, it was still at 33. Throughout this period, the EU average remained at $30 .{ }^{26}$ Other inequality indicators, such as inequality of income distribution, show similar results. As regards the income quintile share ratio, which is the ratio of total income received by the $20 \%$ of the population with the highest income (top quintile) to that received by the $20 \%$ of the population with the lowest income (lowest quintile), ${ }^{27}$ the EU average remained around 5 (5.01 in 2008 and

\footnotetext{
${ }^{24} \mathrm{https}$ //ec.europa.eu/eurostat/databrowser/view/tps00203/default/table?lang=en

${ }^{25}$ The concept of social exclusion used in the FOESSA report is much more restrictive than economic povery, since it combines several secial problems beyond the lack of sufficient income.

${ }^{26} \mathrm{https}$ ://ec.europa.eu/eurostat/web/income-and-living-conditions/data/main-tables

${ }^{27} \mathrm{https}: / /$ ec.europa.eu/eurostat/databrowser/view/tespm151/default/table?lang=en
} 
5.09 in 2019), while Spain was above the average, with 5.59 in 2008, reaching 6.87 in 2015 and still at 5.94 in 2019.

It seems clear that all these indicators point to a worsening of SDH as relevant as employment, social exclusion and inequality. 2013 and 2014 were the worst years, followed by a slow recovery that never reached pre-crisis levels. All scientific evidence on SDH suggest that this would affect the health of the population, also leading to an increase in health inequalities between social groups with a disproportionate impact on the most vulnerable sectors. On the one hand, there are questions as to what extent this can be quantified and how (separately from health system aspects). On the other, it is uncertain whether these effects will be immediately perceptible or will manifest themselves over longer time periods. In fact, the "life course approach" to the SDH has focused on the longterm consequences - especially of conditions experienced in early childhood (Bartley, 2004: 8), which point to lingering effects over time.

Regarding short-term consequences, there has been controversy surrounding possible increases in mortality related to austerity policies. According to Cabrera de León, there was a significant increase in mortality between 2011 and 2015 attributable to austerity policies (Cabrera de León et al., 2018). However, the alternative Regidor's analysis seems more plausible. In his opinion, the increase in mortality was not so significant (it was only noticeable in 2012 and 2015 within a general context of decline), and in any event it cannot be attributed separately to these policies, taking into account the increased incidence of influenza and summer heat waves in those years (Regidor et al., 2019). In any event, the health effects of the austerity measures implemented in Spain will most likely not be immediate (López Valcarcel and Barber, 2017), and in the short term there are no such extreme manifestations as a significant increase in mortality. There does seem to be evidence of an increase in suicides in that period, although some doubts remain as to their actual quantification (Regidor et al., 2019: 1047). There was also a 20\% increase in severe depressions (Cervero-Liceras et al., 2014).

Despite all these circumstances, certain indirect health indicators remain comparatively good. Life expectancy at birth remains high, leading the European Union (together with Italy), although the gap with the European average has decreased from 6.1 years in 2005 to 5 years in $2019 .{ }^{28}$ However, life expectancy does not run parallel to Healthy life years - 68 years is above the European average but still far from Sweden's 72.8 years, based on 2018 data. $^{29}$

With regard to inequalities in health outcomes between socioeconomic groups in terms of difference in life expectancy, Spain's results continue to be comparatively good. In a study for 15 European countries with data from 2010-2014, Spain showed the smallest difference in partial life expectancy among people aged between 35 and 80 with different levels of education. In all the countries, people with lower levels of education had shorter partial life expectancy, but the average was 3.6 years for men and 1.7 for

\footnotetext{
${ }^{28} \mathrm{https}: / /$ ourworldindata.org/life-expectancy

${ }^{29} \mathrm{https}$ ://ec.europa.eu/eurostat/databrowser/view/hlth_hlye/default/table?lang=en
} 
women, while in Spain it was reduced to 2.1 and 0.6 respectively (Mackenbach et al., 2019). Data from the following years will allow us to determine whether this difference has been increasing, according to medium-term projections based on the deterioration of certain SDH.

\section{ELEMENTS FOR STRENGTHENING THE RIGHT TO HEALTH.}

The previous sections point at some alarming issues regarding the management of the pandemic as it has come to the fore. This is not to paint a gloomy picture of the state of the right to health in Spain, but to draw attention to some aspects and trends that should be addressed and reversed. On the one hand, policies of cutbacks, commodification and exclusion can have a negative effect on health outcomes. Empirical evidence shows these negative effects, even if it is not possible to determine exactly the relative weight of the possible causes. In any case, the consequences of these policies do not usually manifest themselves immediately, so their full effects will probably only be felt in the medium term. On the other hand, the consequences of the economic and social crisis in terms of unemployment, vulnerability and inequality, as well as the relevant social responses, affect health beyond their effects on health systems. Indeed, they are social determinants of health. Of particular concern, therefore, is the issue of inequality and the increase in the unequal distribution of health determinants. In this area, too, the effects on the health of individuals and populations may manifest themselves primarily, but inexorably, over longer periods of time.

Reversing the causes of these results requires measures that contribute to strengthening the right to health in all its aspects. These are not utopian proposals, since some neighboring countries provide examples of realistic, attainable goals. The equalization of health expenditure in relation to GDP with the best benchmarks, for example, takes as a reference the country's own economic reality, not an ideal, unfeasible model. It is possible to offer some tentative examples of this type of measures.

To begin with, we should seriously adopt a rights-based approach to health, particularly the right to health. This has several implications. First, health care must be seen as a social citizenship right not dependent on other conditions (such as employment status), and which cannot be replaced by approaches based on subsidiarity or charity. Second, the idea of entitlement implies the idea of universality, of an equal right for all people, something that should not be called into question. Third, it must be seen as a right to the determinants of health, which implies a double- health care and socialdimension. Fourth, the international "highest attainable standard of health" requires that any possible regression must be justified as an exceptional measure. Fifth, real safeguard mechanisms are needed to shield or secure the core content of the right from circumstantial political decisions. Extreme and exceptional circumstances like the current pandemic, are occasions to strengthen this rights-based approach, not to set it aside.

A second proposal is to strengthen a non-commodified public health system. The rights-based approach also opposes commodification. Acknowledging health as a right means that access to it should not be at the mercy of the market or dependent on the 
ability to pay. It is simply outrageous to deny someone access to minimal health care or to undermine their outcomes because of their inability to pay or their socioeconomic status. The priority must be the health of individuals and populations rather than business or private profit opportunities. That is why health policy priorities must be set according to scientific evidence as to which social and health policies are the most effective in protecting health. If we commit to a public system, it must give everyone access, far from subsidiary or exclusive approaches. This requirement stems not only from the need to ensure the right to health for all, but also from a demand for real and effective equality. This, in turn, requires a commitment to support the financing efforts.

The third idea is therefore related to a well-financed health system. The "highest attainable standard of health" does not demand the impossible, it does not impose obligations beyond what is economically and financially feasible. It is thus linked, among other things, to the country's wealth and development. The above figures indicate that public spending on health in relation to GDP is far from skyrocketing; it is neither "unsustainable" nor "beyond our means," to quote the oft-repeated rhetoric.

The fourth idea is that of an integral health system. Primary care, community health and public health have traditionally been neglected in health policy priorities. In the wake of the recent crisis, they have also experienced the greatest cuts. It is necessary to prioritize them, just as it is necessary to take decisive action on the social determinants of health. The challenge is not to lose the results achieved by the public health system and to incorporate this integral approach to health that gives more attention to the social health and public health aspects. Public health crises like the COVID-19 pandemic make this idea evident, but the integral health approach contributes to improve health in any circumstances. Only in this way will it be possible to guarantee true equality and equity in the protection of the right to health.

The fifth idea refers to a democratic health system. Citizen and community participation in collective health and in the health system itself is not alien to the development of the right to health in Spain. In fact, it is present in the General Health Act in at least two aspects. On the one hand, the General Health Act provides a set of mechanisms so that the holders of the right to health can demand compliance from public authorities, while at the same time establishing and systematizing a patients' bill of rights. But, above all, it allows for community participation, since the patient's bill of rights includes the right "to participate through community institutions in health activities" (art. 10(10)). These provisions remained little more than wishful thinking, and in fact were reduced to the possibility of participation through the NHS Council for Social Participation (Consejo de Participación Social) — where only trade unions and business associations are represented in addition to public authorities. The social response to the attacks on the right to health is a living example of this participation outside institutional channels: there is a civic energy that is not content with merely enjoying health services or passively watching their deterioration.

The sixth idea is the promotion of health equity. In addition to guaranteeing the right to health, public health systems that provide universal and quality care generate social equality: 
few public policies can be more effective for equality than health policies. However, not even the most sophisticated among these systems have been able to break the link between socioeconomics and health outcomes. That is due to the SDH. Even with equal access to the health system, health outcomes vary according to social and economic hierarchies. Such inequalities are profoundly unjust and call into question the right to health, which thus ends up not being equal for all. The right to health cannot be limited to the universal and equal right to health care, even if this is an indispensable minimum. It must be extended, because the right to health care alone cannot guarantee the health of all people in the same way and under equal conditions. The imperative of justice demands to prioritize action on the social determinants of health in order to achieve minimum health equity — ensuring that everyone's right to health is guaranteed without arbitrary differences.

The above are just a few ideas for strengthening the right to health in Spain, trying to cast a positive light on an analysis that has revealed certain shortcomings - and some strengths. Naturally, there are many other specific aspects. However, if the initial diagnosis (namely, that the difficulties in confronting the COVID-19 pandemic emerged in a framework that "had depleted the health workforce and reduced public health and health system capacities") is true, the urgent fight against the pandemic will have to be combined with a far-reaching look at the consolidation and improvement of the health system, as well as the guarantee of the right to health. According to the assess of the right to health that this article suggests, the improvement of its guarantee must address in its twofold dimension: health care and social determinants of health.

\section{REFERENCES}

AI, Amnestiy International (2020) Abandonadas a su suerte. La desprotección y discriminación de las personas mayores en residencias durante la pandemia Covid-19 en España. Madrid: Amnistía Internacional.

Álvarez González EM (2007) El Sistema Nacional de Salud como sistema: realidad y carencias. Derecho y Salud, 15(1): 1-28.

Añón MJ (2016) ¿Hay límites a la regresividad de derechos sociales?. Derechos y Libertades, 34:57-90.

Arcà E, Principe F, Doorslaer E (2020) Death by Austerity? The Impact of Cost Containment on Avoidable Mortality in Italy. Health Economics, 29(12):1500516. https://doi.org/10.1002/hec.4147

Bambra C, et al. (2020) The COVID-19 pandemic and health inequalities. Journal of Epidemiology and Community Health, 74:964-968. https://doi.org/10.1136/jech2020-214401

Bartley M (2004) Health inequality. An introduction to theories, concepts and methods. Cambridge: Polity Press.

Benach J, et al. (2012) La sanidad está en venta. Y también nuestra salud. Barcelona: Icaria. 
Borra C, Pons-Pons J, Vilar-Rodriguez M (2020) Austerity, healthcare provision, and health outcomes in Spain. The European Journal of Health Economics, 21(7): 409-423. https://doi.org/10.1007/s10198-019-01141-3

Cabrera de León A, et al. (2018) Austerity Policies and Mortality in Spain After the Financial Crisis of 2008. Am J Public Health. Aug;108(8):1091-1098. https://doi. org/10.2105/AJPH.2018.304346

Calvo M (2013) Crisis económica y efectividad de los derechos sociales, en Bernuz, MJ y Calvo M (eds.), La eficacia de los derechos sociales. Valencia: Tirant Lo Blanch, 89-132.

Cervero-Liceras F, Mckee M, Legido-Quigley H (2014) The Effects of the Financial Crisis and Austerity Measures on the Spanish Health Care System: A Qualitative Analysis of Health Professionals' Perceptions in the Region of Valencia. Health Policy, 119(1):100-106. https://doi.org/10.1016/j.healthpol.2014.11.003

Commission on Social Determinants of Health (2008), Closing the gap in a generation. Health equity through the social determinants of health. Geneva: World Health Organization.

Ehni H-J, Wiesing U, Ranisch R (2020) Saving the most lives. A comparison of European triage guidelines in the context of the COVID-19 pandemic, Bioethics:00 1- 10 . https://doi.org/10.1111/bioe.12836

Escobar Roca G (2008) Filosofía y dogmática en la configuración del derecho fundamental a la protección de la salud, en Estudios en homenaje al profesor Gregorio PecesBarba, vol. 3. Madrid: Dykinson, 523-558.

Esping-Andersen G (1990) The Three Worlds of Welfare Capitalism. Princeton: Princeton University Press. https://doi.org/10.1177/095892879100100108

FOESSA (2014), VII Informe Sobre Exclusión y Desarrollo Social en España 2014. Madrid: Cáritas Española.

FOESSA (2019), VIII Informe Sobre Exclusión y Desarrollo Social en España 2019. Madrid: Cáritas Española.

García-Basteiro A (2020a) The Need for an Independent Evaluation of the COVID-19 Response in Spain. The Lancet, 396(10250):529-30. https://doi.org/10.1016/ S0140-6736(20)31713-X

García-Basteiro A, et al. (2020b) Evaluation of the COVID-19 Response in Spain: Principles and Requirements. The Lancet. Public Health, 5(11):E575. https://doi. org/10.1016/S2468-2667(20)30208-5

Garrett L (2001) Betrayal of trust. The collapse of global public health. Oxford: Oxford University Press.

Gemmill MC, Thomson S, Mossialos E (2008) What impact do prescription drug charges have on efficiency and equity? Evidence from high-income countries. 
International Journal for Equity in Health, 7, 12 https://doi.org/10.1186/14759276-7-12

González Suárez G (2020) Análisis ético y jurídico sobre los criterios de priorización en las unidades de cuidados intensivos. Derecho y salud, 30(2):44-56.

Hassoun N (2020) The Human Right to Health: A Defense. Journal of Social Philosophy, 51(2):158-79. https://doi.org/10.1111/josp.12298

Hofrichter R (ed.) (2000) Health and Social Justice. Politics, ideology, an inequity in the distribution of disease. San Francisco: Jossey-Bass.

Horton R (2020) COVID-19 Is Not a Pandemic. The Lancet, 396(10255):874. https://doi. org/10.1016/S0140-6736(20)32000-6

House JS, Williams D (2000) Understanding and Reducing Socioeconomic and Racial/ Ethnic Disparities in Health, in R. Hofrichter (ed.), Health and Social Justice. Politics, ideology, an inequity in the distribution of disease. San Francisco: JosseyBass, pp. 89-131.

ISCIII, Instituto de Salud Carlos III (2020), Estudio ENE-COVID: Cuarta Ronda. Estudio Nacional de Sero-Epidemiología de la infección por SARS-CoV-2 en España. 15 de diciembre de 2020. Madrid, Instituto de Salud Carlos III. https://portalcne.isciii. es/enecovid19/informes/informe_cuarta_ronda.pdf

Jöbges S, et al. (2020) Recommendations on COVID-19 Triage: International Comparison and Ethical Analysis. Bioethics, 34(9):948-59. https://doi. org/10.1111/bioe.12805

Karanikolos M, et al. (2013) Financial Crisis, Austerity, and Health in Europe. The Lancet, 381(9874):1323-331. https://doi.org/10.1016/S0140-6736(13)60102-6

Legido-Quigley H, et al. (2013) Will Austerity Cuts Dismantle the Spanish Healthcare System?. British Medical Journal, 346(Jun13):F2363. https://doi.org/10.1136/ bmj.f2363

León Alonso M (2009) La protección constitucional de la salud. Madrid: La Ley.

Lopez-Valcarcel B, Barber P (2017) Economic Crisis, Austerity Policies, Health and Fairness: Lessons Learned in Spain. Applied Health Economics and Health Policy, 15(1):13-21. https://doi.org/10.1007/s40258-016-0263-0

Mackenbach J, et al. (2019) Determinants of inequalities in life expectancy: an international comparative study of eight risk factors. The Lancet Public Health, 4/10:e529-e537, https://doi.org/10.1016/S2468-2667(19)30147-1

Marmot M, Wilkinson R (2006) Social Determinants of Health. New York: Oxford University Press. https://doi.org/10.1093/acprof:oso/9780198565895.001.0001

McKeown T (1976) The Modern Rise of Population. London: Edward Arnold.

Menéndez Rexach A (2003) El derecho a la asistencia sanitaria y el régimen de las prestaciones sanitarias públicas. Derecho y Salud, 11(1):15-36. 
Ministerio de Sanidad (Ministry of Health) (2020), Informe del Ministerio de Sanidad sobrelos aspectos éticos ensituaciones de pandemia: El SARS-CoV-2 (3 de abril de 2020) https://www.mscbs.gob.es/profesionales/saludPublica/ccayes/alertasActual/ nCov/documentos/AspectosEticos_en_situaciones_de_pandemia.pdf (consultado el $4 / 1 / 2020$ )

Monereo JL, Molina C (2007) La Asistencia sanitaria como derecho fundamental y el sistema nacional de salud como garantía institucional: Balance y desafíos para el siglo XXI de su modelo regulador. en Comentario Práctico a la legislación reguladora de la sanidad en España. Granada: Comares, 3-50.

OECD/European Union (2020), Health at a Glance: Europe 2020: State of Health in the EU Cycle. Paris: OECD Publishing, https://doi.org/10.1787/82129230-en.

Palasca S, Jaba E (2015) Economic Crisis' Repercussions on European Healthcare Systems. Procedia Economics and Finance, 23:525-33. https://doi.org/10.1016/ S2212-5671(15)00568-7

Pemán Gavín J (1989) Derecho a la salud y administración sanitaria. Bolonia: Publicaciones del Real Colegio de España.

Pemán Gavín J (2008) Sobre el derecho constitucional a la protección de la salud. Derecho y Salud, 16:29-62

Pollán M, et al. (2020) Prevalence of SARS-CoV-2 in Spain (ENE-COVID): A Nationwide, Population-based Seroepidemiological Study. The Lancet, 396(10250): 535-44. https://doi.org/10.1016/S0140-6736(20)31483-5

Regidor E, Alberto Mateo, Gregorio Barrio, and Luis de la Fuente (2019) Mortality in Spain in the Context of the Economic Crisis and Austerity Policies. American Journal of Public Health, 109(7):1043-049. https://doi.org/10.2105/AJPH.2019.305075

Ruhm CJ (2000) Are Recessions Good For Your Health?. Quarterly Journal of Economics, 115(2):617-650. https://doi.org/10.1162/003355300554872

Santos B (1992) O Estado, a Sociedade e as políticas sociais: o caso das políticas de saúde. en $O$ Estado e a sociedade em Portugal (1974-1988). Porto: Afrontamento.

Sassen, S (2014) Expulsions. Brutality and Complexity in the Global Economy, CambridgeMassachusetts, London-England, The Belknap Press of Harvard University Press. https://doi.org/10.4159/9780674369818

Schmidt H (2020) Vaccine Rationing and the Urgency of Social Justice in the Covid-19 Response. The Hastings Center Report, 50(3):46-49. https://doi.org/10.1002/ hast.1113

Singer M (2009) Introduction to Syndemics: A Systems Approach to Public and Community Health. San Francisco: Jossey-Bass.

Stuckler D, Basu S (2013) The Body Economic. Why Austerity Kills. London: Allen Lane.

Stuckler D, et al. (2017) Austerity and health: the impact in the UK and Europe. European Journal of Public Health, 27(4):18-21. https://doi.org/10.1093/eurpub/ckx167 
The Lancet (2020) COVID-19 in Spain: A Predictable Storm?. The Lancet. Public Health, 5(11):E568. https://doi.org/10.1016/S2468-2667(20)30239-5

Toebes B (2006) The Right to Health and the Privatization of National Health Systems: The Case Study of the Netherlands. Health and Human Rights, 9(1):103-127. https://doi. org $/ 10.2307 / 4065392$

United Nations - Economic and Social Council- Committee on Economic, Social and Cultural Rights UN-ESC (2018) "Concluding observations on the sixth periodic report of Spain”, E/C.12/ESP/CO/6, 25 April 2018, http://docstore.ohchr.org/SelfServices/ FilesHandler.ashx? enc $=4$ s1Q6QSmlBEDzFEovLCuW1SKyxvprlxEitT 1iPv5tsG80ELH301p\%2bURW\%2fv0pMkQcf61 TicGbfUD\%2bE8x0cF6 WYYM778UpzlrUblhJ9r0bs0EL2J7qf7UtzVrUrdKNocu0

United Nations Committee on Economic, Social and Cultural Rights (CESCR) (2000) General Comment No. 14: The Right to the Highest Attainable Standard of Health (Art. 12 of the Covenant), 11 August 2000, E/C.12/2000/4

Vallejo-Torres L, García-Lorenzo B, Serrano-Aguilar P (2018) Estimating a Costeffectiveness Threshold for the Spanish NHS. Health Economics, 27(4):746-61. https://doi.org/10.1002/hec.3633

WORLD HEALTH ORGANIZATION (WHO) (2016), Social justice and human rights as a framework for addressing social determinants of health. Final report of the Task group on Equity, Equality and Human Rights. Review of social determinants of health and the health divide in the WHO European Region. Copenhagen: WHO.

Received: February $18^{\text {th }} 2021$

Accepted: April 30 2021 